\title{
Research on Strategic Supplier Selection and Evaluation Standard System of Manufacturing Enterprise
}

\author{
Banglei $\mathrm{Wu}^{1, \mathrm{a}}$, Jing $\mathrm{Yu}^{1, \mathrm{~b}}$ and Qing Sun ${ }^{1, \mathrm{c}}$ \\ ${ }^{1}$ Economic and Management Department, Anhui Technical College of Mechanical and Electrical \\ Engineering, Wuhu Anhui 241000, China \\ awubanglei@126.com, byujing625@126.com, cahjdsq617@126.com
}

Keywords: strategic supplier, selection and evaluation system

\begin{abstract}
With the market competition aggravating, strategic supplier of manufacturing enterprise is becoming more and more critical for the success of manufacturing enterprise. It plays decisive role in the areas of product quality, date of delivery, service, etc. At present, there are many methods on selection and evaluation of strategic supplier of manufacturing enterprise. But, there lacks of integral system. Through the establishment of outsourcing criteria to supplier classification based on products, this paper builds selection and evaluation standard system of strategic supplier of manufacturing enterprise in order to provide reference to manufacturing enterprise on choosing strategic supplier.
\end{abstract}

\section{Introduction}

With the development of world economy from globalization, integration to regional integration, information technology, and the popularization of internet, the information between enterprises and between enterprises and consumers is more and more symmetrical and the market competition is becoming fiercely day by day. It is no long mere competition between enterprises, but turning out to be competition between supply chains. Research shows that 30 percent of the quality problems and 80 percent of the products delivery time problems of the manufacturing enterprise are caused by the supplier [1]. The competition between supply chains is becoming much more acute due to slathering of advanced manufacturing technology. Manufacturing enterprises become more rigid with suppliers which rank in the upper reaches of supply chain. With the forsaking of non-core production activity, enterprises focus on core products or services thus leading to increasing mutual reliance on each other [2]. But at the same time the risk of cooperation is rising. Thus how to choose outsourcing, how to confirm supplier classification of outsourcing and how to select and evaluate strategic supplier appears very important. From the long time practice of manufacturing enterprises, any strategic supplier of manufacturing is very crucial to the self development of enterprises. It is because the effects that strategic supplier have on performance of the whole supply chain are increasingly outstanding that the study on selection and evaluation system of strategic supplier is of top priority.

\section{Outsourcing Policy}

No enterprise can gain competitive edge in all business areas. The resource that one enterprise can own is limited, thus one must put the limited resource on core business. Therefore it is one key aspect to know how to integrate internal resource and external resource in order to adapt to environment. This is also the starting point between enterprise self production and business outsourcing. In nature, any outsourcing decision is not simply choice between self production and outsourcing, but decision made by decision makers based on analyzing enterprise core competitiveness, enterprise external environment, enterprise management strategy, competition strategy of main competitors, technology restraints on products, etc.

In considering core competitiveness, the first thing to do is to confirm core resources like material resource, knowledge resource of enterprise. And analyze excellent market performance of business based on such foundation. For manufacturing enterprise, it may have very powerful cost advantage or it can bring business which is different, hard to copy and of technology or brand ductility and beyond 
comprehension value of targeted consumers to have core competiveness. Enterprise external environment's restraint on outsourcing decision is manifested in the easy access to external resources problem and cost conversion problem. Outsourcing decision is directly related to management strategy of enterprise. In other word, outsourcing decision has to comply with overall enterprise management strategy. Enterprise overall strategy's urgency and permanence can be slightly considered only when there is specific business outsourcing. When considering competitive strategy of main competitors, we can draw support from Porter's Five Forces Model to make specific analysis which mainly focuses on negotiation advantage and disadvantage [3]. Product technology restriction can be considered when analyzing corporate core competitiveness. However, from the perspective of management practice, attentions are more often attracted to the already owned resource and capability when analyzing core competitiveness. At the same time, when analyzing enterprise product technology's restraints on outsourcing decision, the application of new technology in the industry must be considered.

The above analyses lead to theoretical basis of outsourcing decision of manufacturing enterprises. They are shown in table 1.

Table 1. Elements of outsourcing decision

\begin{tabular}{|l|c|c|}
\hline elements of outsourcing decision & outsourcing & self-produced \\
\hline 1.core business & & yes \\
\hline 2.extrenal environment & yes & \\
\hline easy access to resource and specific economy of scale & yes & \\
\hline abundant suppliers & & \\
\hline 3.enterprise management strategy & & yes \\
\hline regarding accumulation of experience as goal & yes \\
\hline carrying out differentiatation & yes & \\
\hline $\begin{array}{l}\text { low cost oriented and getting more advantage from } \\
\text { external environment }\end{array}$ & & \\
\hline 4.competitors & & yes \\
\hline $\begin{array}{l}\text { the direct competitors have close benefits relations with } \\
\text { suppliers and single-sourced relationship }\end{array}$ & yes & \\
\hline $\begin{array}{l}\text { suppliers have greater market concentration and } \\
\text { can build price negotiation mechanism }\end{array}$ & & yes \\
\hline $\begin{array}{l}\text { suppliers are scattered and quality is not easily } \\
\text { guaranteed }\end{array}$ & yes & yes \\
\hline substitute products has certain advantage in price and quality & \\
\hline $\begin{array}{l}\text { 5.product } \\
\text { whether need expertise }\end{array}$ & yes \\
\hline whether have related business secrete & \\
\hline whether need large amount of money or labor input & \\
\hline
\end{tabular}

\section{Supplier Classification of Manufacturing Enterprises}

The purpose of supplier classification is for manufacturing enterprises to have better outsourcing decision, selection and evaluation of supplier and later management. So whether it is outsourcing decision, supplier selection and evaluation or late management, the nature of supplier is enterprises' outsourcing products. So the nature of this issue is to implement functionalization analysis, modularization analysis and universalization analysis of product from the product itself and make outsourcing decision according to above decision-making criteria and in this way, find several 
suppliers for enterprise outsourcing business. According to supplier management practice of manufacturing enterprise, different type of suppliers should be managed with different ways.

Figure 1 shows that when classifying suppliers, there are two aspects that should be mainly considered: one aspect is the judgment on importance of products provided by suppliers to manufacturing enterprises, the other is the judgment on the complexity degree of supply market. In this way, suppliers are categorized in four groups which are explained as follows.

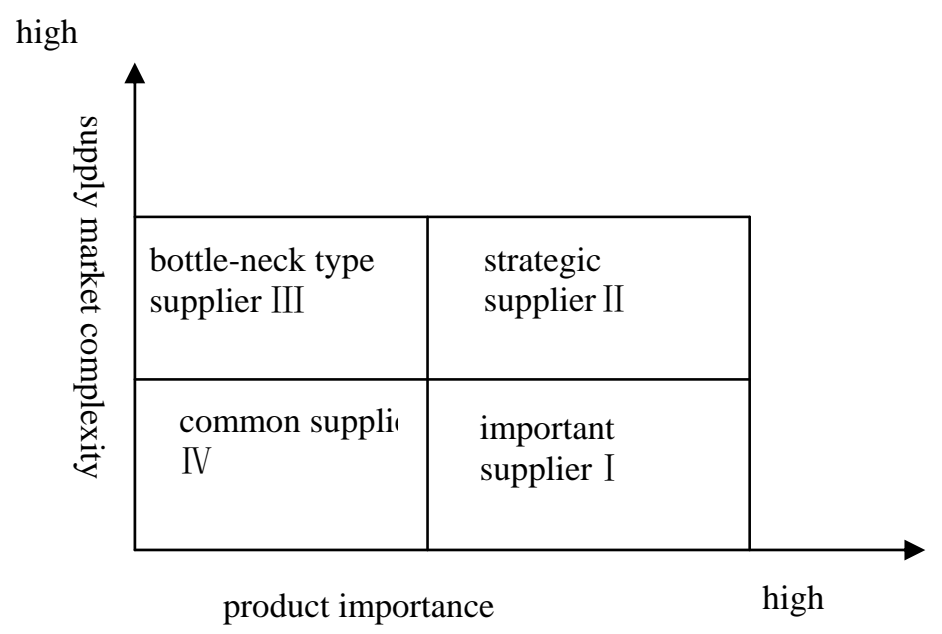

Fig.1.Classification of suppliers

Strategic supplier: product provided by this kind of supplier is very important to manufacturing enterprises. At the same time, supply market is quite complicated. It has certain degree of difficulty to acquire such raw material. So this kind of raw material has strategic meaning to manufacturing enterprises.

Important raw material supplier: product provided by this group of supplier is very important to manufacturing enterprises. But it is easy to get this kind of product. You need to pay much money for it. But in the aspect of prompt supply, there is little risk that it brings to manufacturing enterprises.

Bottle-neck type of supplier: product provided by this kind of supplier is not of much importance. but supply market is rather complex, so the supply is not dependable.

Common supplier: product provided by this kind of supplier is not of much importance to manufacturing enterprise and is easy to get. Usually, this kind of product is routine item, commodity or service. It will not directly add the additional value of final product and is usually of low cost.

All in all, supplier classification based on products is following : functionalization,modularization, univeralizatinon--parts unfolding--outsourcing/self-produced--raw material synthesizing--supplier classification principle--forming different suppliers.

According to the idea of functionalization, modularization and universalization, Fig.2 shows the supplier classification model of $\mathrm{C}$ corporation. $\mathrm{C}$ corporation divide its power-operated sliding door into seven functional module: lock system, drive system, sliding door, ECU, window glass lifter, track system, hinge system (see Fig.2). 

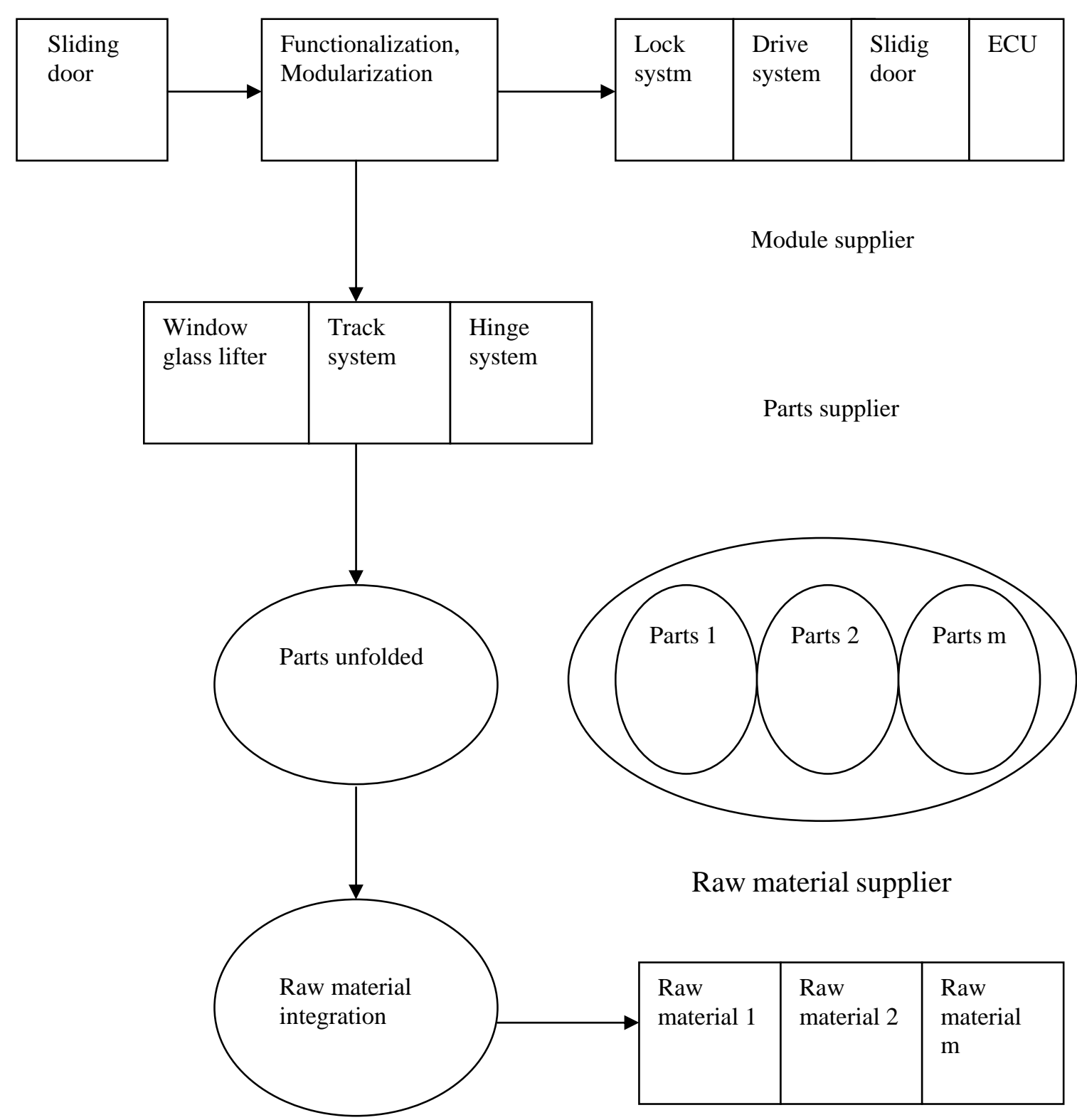

Fig.2. Supplier classification model of C corporation

According to the above mentioned manufacturing enterprise business outsourcing decision theory, lock system, drive system, sliding door, ECU has the necessity and condition to outsourcing in the aspects of core business, external environment, enterprise management strategy, competitor and product elements. Window glass lifter, track system and hinge system satisfy the requirement and need of self -production. Continue to decompose the self-produced module products in the thought of functionalization, modularization and universalization, it gets various parts. Then the corporation finds out parts that need outsourcing according to outsourcing decision theory. It also finds out what kinds of raw material need outsourcing by synthesizing all the raw material that used in production. By analyzing the importance of products and raw material provided by outsourcing and raw material supplier to $\mathrm{C}$ corporation and complexity degree of supply market, $\mathrm{C}$ corporation finds out that suppliers of four outsourcing modules and a proportion of parts are strategic suppliers, some parts suppliers are bottle neck suppliers, and raw material suppliers can be divided into two types: important suppliers and common suppliers. 


\section{Standard of Selection and Evaluation of Strategic Supplier of Manufacturing Enterprise}

Through research on Japanese and American enterprises which have close relationship with suppliers, the strategic cooperation partnership between purchasers and suppliers is considered a key element for manufacturing enterprises to reach the goal of good quality, fast delivery, and continuous improvement with the rapid development of manufacturing technology. Standard of selection and evaluation of strategic supplier of manufacturing enterprise is the first and foremost condition to realize this goal. So far, most manufacturing enterprises mainly follow the following standards when carrying out selection and evaluation of suppliers, respectively, they are: quality, cost, date of delivery, service. And there also have key performance indicators( KPI) assessment every year. What have been assessed are result elements of suppliers' output. There lacks of process elements to guide and improve supplier relationship. Thus manufacturing enterprises can not master suppliers essentially. For selection and evaluation of strategic suppliers, this is far from enough.

Table 2 shows standards for selection and evaluation of strategic supplier of manufacturing enterprise. Strategic supplier plays vital role for manufacturing enterprise in formation of core competitiveness and excellent market performance. we can conduct selection and evaluation of strategic supplier from nine aspects, namely, they are: product competitive edge, management level, flexibility, research and development capability, information and technology application, financial condition, enterprise compatibility, external environment. What is more, description of each standard is given in table 2 .

Table 2. Standards for selection and evaluation of strategic supplier of manufacturing enterprise

\begin{tabular}{|c|c|c|c|c|c|}
\hline & Index B & Index C & specificat & ion & \\
\hline & & & good & 9 & $\begin{array}{l}\text { Perfect quality system document, } \\
\text { explicit TQM organization } \\
\text { structure, pass certifications like } \\
\text { ISO9001 }\end{array}$ \\
\hline & & $\begin{array}{l}\text { Quality system（qualitative } \\
\text { diagnosis ) C1 }\end{array}$ & mediocre & 6 & $\begin{array}{l}\text { Have relatively good quality } \\
\text { document and quality } \\
\text { management structure, problems } \\
\text { still exist, mediocre effects of } \\
\text { quality management }\end{array}$ \\
\hline $\begin{array}{l}\text { C } \\
\text { company } \\
\text { strategic } \\
\text { supplier }\end{array}$ & Product & & bad & 3 & $\begin{array}{l}\text { Not pass quality system } \\
\text { certification or not examined and } \\
\text { verified by the company itself ,no } \\
\text { standard document, bad quality } \\
\text { management effects. }\end{array}$ \\
\hline and & $\begin{array}{l}\text { edge } \\
\text { B1 }\end{array}$ & $\begin{array}{l}\text { Product failure } \\
\text { rate(quantitative } \\
\text { diagnosis )C2 }\end{array}$ & $\begin{array}{l}\text { Product } \mathrm{f} \\
\text { amount } / \mathrm{n} \\
\text { period of }\end{array}$ & & $\begin{array}{l}\text { re rate }=\text { defective products } \\
\text { ber of units produced in certain } \\
\mathrm{e} \times 1,000,000 \mathrm{ppm} \text {. }\end{array}$ \\
\hline system A & & $\begin{array}{l}\text { Synthetic cost(quantitative } \\
\text { diagnosis )C3 }\end{array}$ & $\begin{array}{l}\text { Synthetic } \\
\text { +adminis }\end{array}$ & 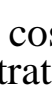 & $\begin{array}{l}\mathrm{t}=\text { purchase price }+ \text { purchase cost } \\
\text { ion cost }+ \text { financial cost }\end{array}$ \\
\hline & & \begin{tabular}{|l|} 
Delivery on time rate \\
(quantitative diagnosis) C4
\end{tabular} & $\begin{array}{l}\text { Delivery } \\
\text { time of p }\end{array}$ & 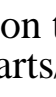 & $\begin{array}{l}\text { time rate }=\text { times of delivery on } \\
\text { /scheduled delivery times } \times 100 \%\end{array}$ \\
\hline & & $\begin{array}{l}\text { Production } \\
\text { capacity( quantitative } \\
\text { diagnosis) C5 } \\
\end{array}$ & $\begin{array}{l}\text { Calculate } \\
\text { supplier }\end{array}$ & & average daily output of a \\
\hline & & $\begin{array}{l}\text { Market share (quantitative } \\
\text { diagnosis) C6 }\end{array}$ & $\begin{array}{l}\text { Sale of Pr } \\
\text { Sa, sale o } \\
\text { is Sta, Sc }\end{array}$ & & $\begin{array}{l}\text { uct A provided by one supplier is } \\
\text { ongeneric product within industry } \\
\text { arket share }=(\mathrm{Sa} / \mathrm{Sta}) \times 100 \%\end{array}$ \\
\hline
\end{tabular}




\begin{tabular}{|c|c|c|}
\hline Index B & Index C & specification \\
\hline \multirow{3}{*}{$\begin{array}{l}\text { Management } \\
\text { level } \\
\text { B2 }\end{array}$} & $\begin{array}{l}\text { Cost control level } \\
\text { (quantitative diagnosis) C7 }\end{array}$ & $\begin{array}{l}\text { Suppose expense by one supplier to carry out } \\
\text { cost control in a certain period of time is C1, } \\
\text { cost saved by taking cost control measures is } \\
\text { C2, so efficiency of cost control in this period } \\
\text { of time is : cost control level = }(\mathbf{C} 2 / \mathbf{C} 1) \times 100 \%\end{array}$ \\
\hline & \begin{tabular}{|l|} 
Inventory control level \\
(quantitative diagnosis) C8
\end{tabular} & $\begin{array}{l}\text { Suppose opening inventory sum/money of } \\
\text { supplier in a certain period of time is K1, } \\
\text { ending inventory sum/money is K2, total sum } / \\
\text { money of delivery from inventory is K3, so } \\
\text { inventory turnover ratio is: inventory control } \\
\text { level= }[\mathrm{K} 3 /(\mathrm{K} 1+\mathrm{K} 2) / 2)] \times 100 \%\end{array}$ \\
\hline & $\begin{array}{l}\text { Service level （quantitative } \\
\text { diagnosis） C9 }\end{array}$ & $\begin{array}{l}\text { Suppose enterprise complained } \mathrm{N} \text { times to } \\
\text { supplier in a certain period of time, among } \\
\text { them the time to solve the number } \mathrm{n} n(1 \leqslant \mathrm{n} \leqslant \\
\mathrm{N}) \text { complaint is } \mathrm{t} \text {, C the time enterprise } \\
\text { consults with supplier is solve the problem is } \\
\text { T, So the formula to calculate complaints } \\
\text { solved satisfactorily percentage is :service } \\
\text { level }=\sum_{1}^{N} n \quad(\mathrm{t} \geqslant \mathrm{T}) \div \mathrm{N} \times 100 \%\end{array}$ \\
\hline \multirow[b]{2}{*}{$\begin{array}{l}\text { Output } \\
\text { amount } \\
\text { flexibility } \\
\text { B3 }\end{array}$} & $\begin{array}{l}\text { Volume of production } \\
\text { flexibility( quantitative } \\
\text { diagnosis)C10 }\end{array}$ & $\begin{array}{l}\text { Because supplier's output and enterprise need } \\
\text { in a certain period of time are usually stable, } \\
\text { suppose output amount of one product } \\
\text { provided by supplier is P, enterprise's needed } \\
\text { amount of this product is Q, so the output } \\
\text { amount flexibility is :output flexibility = (Q/P) } \\
\times 100 \%\end{array}$ \\
\hline & $\begin{array}{l}\text { Delivery } \\
\text { flexibility( quantitative } \\
\text { diagnosis)C11 }\end{array}$ & $\begin{array}{l}\text { With the change of market need, delivery date } \\
\text { of enterprise will change accordingly, the } \\
\text { ability of supplier to adapt to this change is } \\
\text { delivery flexibility, expressed in percentage of } \\
\text { loose period. Suppose there are I works in } \\
\text { supplier, I= } 1 \text { 2、 } 3 \cdots \text { i(item of work),suppose } \\
t \text { is present date, Ii is the latest time for } \\
\text { completing work I,fi is the earliest time for } \\
\text { finishing work i. the delivery flexibility is [4]: } \\
F=\frac{\sum_{i=1}^{I}\left[\left(l_{i}-t\right)-\left(f_{i}-t\right)\right]}{\sum_{i=1}^{I}\left(l_{i}-t\right)}\end{array}$ \\
\hline $\begin{array}{l}\text { Research and } \\
\text { development } \\
\text { ability } \\
\text { B4 }\end{array}$ & $\begin{array}{l}\text { Scientific research expense } \\
\text { rate( quantitative } \\
\text { diagnosis)C12 }\end{array}$ & $\begin{array}{l}\text { Suppose scientific research expense in one } \\
\text { period of time is A, total sales revenue in this } \\
\text { period of time is TS, so the scientific research } \\
\text { expense rate of such supplier is : scientific } \\
\text { research expense rate }=\mathrm{A} \div \mathrm{TS} \times 100 \%\end{array}$ \\
\hline
\end{tabular}




\begin{tabular}{|c|c|c|c|c|}
\hline Index B & Index C & \multicolumn{3}{|c|}{ specification } \\
\hline & $\begin{array}{l}\text { New product development } \\
\text { success rate( quantitative } \\
\text { diagnosis) C13 }\end{array}$ & \multicolumn{3}{|c|}{$\begin{array}{l}\text { Suppose the amount of new products } \\
\text { developed by a supplier in a certain period of } \\
\text { time is TW, among which the number of } \\
\text { successfully developed new product is W, so } \\
\text { the new product development success rate is : } \\
\text { new product development success rate= W/TW } \\
\times 100 \%\end{array}$} \\
\hline & $\begin{array}{l}\text { New product sale } \\
\text { ratio( quantitative } \\
\text { diagnosis) C14 }\end{array}$ & \multicolumn{3}{|c|}{$\begin{array}{l}\text { Suppose new product sales revenue of a } \\
\text { supplier in one period of time is S, the total } \\
\text { revenue in this period of time is TS, so the new } \\
\text { product sale ratio in such period of time is new } \\
\text { product sale ratio= S/TS } \times 100 \%\end{array}$} \\
\hline \multirow{3}{*}{$\begin{array}{l}\text { Manpower } \\
\text { B5 }\end{array}$} & $\begin{array}{l}\text { Professional title } \\
\text { composition } \\
\text { ( quantitative } \\
\text { diagnosis)C15 }\end{array}$ & \multicolumn{3}{|c|}{$\begin{array}{l}\text { Title composition=number of people of } \\
\text { intermediate or senior professional titles } \\
\text { /number of entire staff } \times 100 \%\end{array}$} \\
\hline & $\begin{array}{l}\text { Education background } \\
\text { composition( quantitative } \\
\text { diagnosis) C16 }\end{array}$ & \multicolumn{3}{|c|}{$\begin{array}{l}\text { Education background composition=number of } \\
\text { people of college degree or above /number of } \\
\text { entire stufe } \times 100 \%\end{array}$} \\
\hline & $\begin{array}{l}\text { Training fee } \\
\text { ratio( quantitative } \\
\text { diagnosis)C17 }\end{array}$ & \multicolumn{3}{|c|}{$\begin{array}{l}\text { Staff training fee to sales volume ratio in a } \\
\text { certain period of time: Training fee ratio } \\
=\text { training fee/ sales volueme } \times 100 \%\end{array}$} \\
\hline \multirow{3}{*}{$\begin{array}{l}\text { Financial } \\
\text { condition } \\
\text { B6 }\end{array}$} & $\begin{array}{l}\text { Current ratio( quantitative } \\
\text { diagnosis) C18 }\end{array}$ & \multicolumn{3}{|c|}{ Current ration=liquid assets/liquid lianbilities } \\
\hline & $\begin{array}{l}\text { Return on total asset } \\
\text { rate( quantitative diagnosis) } \\
\text { C19 }\end{array}$ & \multicolumn{3}{|c|}{$\begin{array}{l}\text { Return on total asset }=(\text { net profit after tax }) \\
\text { total assets } \times 100 \%\end{array}$} \\
\hline & $\begin{array}{l}\text { Ratio of liabilities to assets } \\
\text { (quantitative diagnosis) } \\
\text { C20 }\end{array}$ & \multicolumn{3}{|c|}{$\begin{array}{l}\text { Ratio of liabilities to assets =total } \\
\text { liabilities/total assets= ( total liabilities at the } \\
\text { beginning of the period + total liabilities at the } \\
\text { end of the period }) /(\text { total liabilities at the } \\
\text { beginning of the period + total liabilities at the } \\
\text { end of the period }) \times 100 \%\end{array}$} \\
\hline \multirow{4}{*}{$\begin{array}{l}\text { Enterprise } \\
\text { compatibility } \\
\text { B7 }\end{array}$} & \multirow{3}{*}{$\begin{array}{l}\text { Development strategy } \\
\text { compatibility ( quantitative } \\
\text { diagnosis)C21 }\end{array}$} & good & 9 & $\begin{array}{l}\text { Supplier has explicit strategic } \\
\text { development plan, and is in } \\
\text { consistence with manufacturing } \\
\text { enterprise. }\end{array}$ \\
\hline & & mediocre & 6 & $\begin{array}{l}\text { There is difference between } \\
\text { supplier development strategy } \\
\text { and that of manufacturing } \\
\text { enterprise, but the difference does } \\
\text { not matter a lot. }\end{array}$ \\
\hline & & & 3 & $\begin{array}{l}\text { Supplier does not have } \\
\text { development strategy or large } \\
\text { development strategy difference. }\end{array}$ \\
\hline & $\begin{array}{l}\text { Enterprise culture } \\
\text { compatibility ( quantitative } \\
\text { diagnosis)C22 }\end{array}$ & good & & $\begin{array}{l}\text { Supplier has a similar corporate } \\
\text { culture with manufacturing } \\
\text { enterprise, and is very willing to } \\
\text { cooperate with enterprise. }\end{array}$ \\
\hline
\end{tabular}




\begin{tabular}{|c|c|c|c|c|}
\hline Index B & Index C & \multicolumn{3}{|c|}{ specification } \\
\hline & & mediocre & 6 & $\begin{array}{l}\text { Rather different corporate } \\
\text { culture, but little conflict in } \\
\text { culture, and the possibility to } \\
\text { cooperate with enterprise is very } \\
\text { potential. }\end{array}$ \\
\hline & & bad & 3 & $\begin{array}{l}\text { Large culture difference and } \\
\text { probable conflicts in culture are a } \\
\text { lot. }\end{array}$ \\
\hline & \multirow{3}{*}{$\begin{array}{l}\text { Information platform } \\
\text { compatibility ( quantitative } \\
\text { diagnosis)C23 }\end{array}$} & good & 9 & $\begin{array}{l}\text { Have very good compatibility in } \\
\text { information system structure, } \\
\text { data format, storage medium, } \\
\text { transmission channels, etc. }\end{array}$ \\
\hline & & mediocre & 6 & $\begin{array}{l}\text { Some difference is the above } \\
\text { mentioned elements, but can be } \\
\text { modified and the cost of } \\
\text { modifying is low. }\end{array}$ \\
\hline & & bad & 3 & $\begin{array}{l}\text { It is very difficult to be } \\
\text { compatible with the system, large } \\
\text { cost input is needed. }\end{array}$ \\
\hline
\end{tabular}

\section{Conclusion}

It is very necessary for enterprise to consider outsourcing reasonably in its practice. Adjustment needed to be made by decision-maker in the actual application according to the actual situation. Supplier classification based on products is restored to the nature of supplier selection that is product corresponds to supplier, not the vice versa.

Selection and evaluation system built on nine aspects namely product competitive edge, management level, flexibility, research and development capability, information and technology application, financial condition, enterprise compatibility and external environment reflects overall competence of strategic supplier of manufacturing enterprise, providing great reference for manufacturing enterprise to construct long term and steady supply chain.

\section{References}

[1] Willis T, Huston C, Vendor Requirements and Evaluation in a JIT Environment Vendor, J. International Journal of Operations and Production Management.2 (1990) 4105.

[2] Shihua Ma, Yong Lin, Supply chain management, Mechanical Industry Publishing House, Beijing, 2000.

[3] Michael E. Porter, competitive advantage, Huaxia Publishing House, Beijing, 2005.

[4] Mingfang Li, Yuanyuan Lu, Evaluation Index \& Model of SC Competitiveness, J. Logistics technology. 26 (2007) 68-71. 